\title{
SCREENING KESEHATAN SISTEM REPRODUKSI PEREMPUAN MENOPAUSE DI SATU GEREJA, DI TANGERANG
}

\author{
${ }^{1}$ Eva Berthy Tallutondok., ${ }^{2}$ Prisca Adipertiwi Tahapary., ${ }^{3}$ Fransiska Ompusunggu., \\ ${ }^{4}$ Belet Lydia Ingrit., ${ }^{5}$ Dwi Yulianto Nugroho
}

\author{
1,2,3,4,5 Fakultas Keperawatan - Universitas Pelita Harapan \\ eva.tallutondok@uph.edu, prisca.adipertiwi@uph.edu, fransiska.ompusunggu@uph.edu, \\ belet.ingrit@uph.edu, dwi.nugroho@uph.edu
}

\begin{abstract}
Abstrak
Periode menopause adalah kejadian dimana ovarium sebagai salah satu organ sistem reproduksi yang akan menghasilkan sel telur dan hormon estrogen mengalami penurunan fungsi seiring bertambahnya umur secara alamiah, sehingga perempuan tidak lagi mengalami proses menstruasi secara berkala. Perubahan hormon estrogen selain menimbulkan proses menopause, juga akan menimbulkan dampak perubahan fisik maupun psikologis. Namun, perempuan tidak memahami perubahan tersebut, sehingga perempuan tidak peka untuk melakukan pemeriksaan atau screening terkait dengan penurunan fungsi reproduksi yang dapat berdampak pada penurunan kognitif. Tujuan mendeteksi derajat kesehatan terkait peredaran darah di jantung dan otak, index memori - otak, tingkat kepadatan tulang, kadar gula dalam darah, dan organ sistem reproduksi perempuan. Kegiatan ini dilakukan dengan melakukan screening kesehatan untuk mendeteksi dini kesehatan perempuan masa menopause dengan menggunakan alat Quantum Resonance Magnetic Analyzer. Peserta dilakukan screening $(\mathrm{n}=30)$ pada usia $\geq 60$ tahun (50\%) dan hasil screening dikategorikan dalam tiga yaitu normal, berhati-hati, dan berisiko. Data diketahui peredaran darah di jantung dan otak (96.67\%) pada kategori "berhati-hati" dan kategori "resiko" pada masalah kadar gula dalam darah (76.67\%). Hasil screening disampaikan kepada dokter di klinik gereja untuk ditindaklanjuti pada pemeriksaan diagnostik di rumah sakit. Kesimpulan yaitu lebih dari setengah populasi responden memerlukan pemeriksaan lebih lanjut untuk meningkatkan derajat kesehatan masa menopause.
\end{abstract}

Kata Kunci : Screening, Reproduksi, Perempuan Menopause

\section{PENDAHULUAN}

Periode terjadinya menopause adalah ketika pasokan persediaan sel telur habis sehingga pematangan sel telur terhenti dan mengakibatkan penurunan kadar hormon estrogen dan progesteron. Adanya penurunan kedua hormon ini mengakibatkan perubahan fisik maupun perubahan kognitif.

Perubahan fisik yang dapat terjadi akibat penurunan produksi estrogen dan progesteron yaitu dapat berupa perubahan mulai dari rambut hingga ke kaki dan organ - organ fisik lainnya. Perubahan fisik ini dapat mengakibatkan timbulnya berbagai gejala, baik yang berhubungan dengan organ reproduksi maupun organ tubuh lainnya. Perubahan fisik yang terjadi yaitu penurunan fungsi sistem tubuh contohnya seperti gangguan pada sistem pencernaan, sistem perkemihan, sistem pernafasan, sistem kardiovaskular, sistem endokrin dan sistem panca indera.

Hal mendasar yang perlu diperhatikan dari seorang perempuan menapouse adalah perubahan 
sistem endokrin yang mempengaruhi kadar hormon estrogen dalam tubuh. Sayangnya, belum semua perempuan menapouse mempunyai kesadaran untuk melakukan pemeriksaan atau screening terkait dengan penurunan fungsi reproduksi yang dapat berdampak pada penurunan kognitif. Oleh karena itu para perempuan menapouse harus selalu dilakukan screening khusus fungsi reproduksi dan fungsi kognitif.

Khusus pada penurunan fungsi kognitif, maka setiap perempuan menapouse dengan umur diatas 50 tahun pasti mengalami penurunan fungsi hormon estrogen. Penurunan hormon estrogen memiliki efek signifikan terhadap suasana hati dan emosi yang dihasilkan, karena semua efek tersebut langsung mengacu pada melatonin, dopamin, serotonin dan nonepinefrin. Semua efek tersebut dapat menyebabkan perubahan suasana hati yang tidak stabil dan menyebabkan kecemasan selama menopause (North American Menopause Sosiety, 2016). Penurunan kadar hormon estrogen akibat proses penuaan, maka fungsi kognitif akan mengalami cognitive aging yang ditandai oleh adanya pelupa dan dapat menjadi Mild Cognitive Impairment (MCI) dan dementia jika otak tidak diaktivasi secara optimal (Kim, Jung, 2015).

Badan Pusat Statistik (BPS, 2015) mencatat bahwa sindrom menopause dialami oleh hampir seluruh wanita di dunia, sekitar $70-80 \%$ wanita Eropa, 60\% di Amerika, 57\% di Malaysia, 18\% di Cina di Jepang dan di Indonesia. Peningkatan jumlah wanita menopause di Indonesia terjadi dari $11 \%$ pada tahun 2005 menjadi 15\% pada tahun 2015. Jumlah dan proporsi penduduk perempuan yang memasuki usia menopause mengalami peningkatan yang signifikan setiap tahunnya.

Gereja tersebut mempunyai sebelas sektor pelayanan (sekpel) dan setiap sekpel mempunyai Pelayanan Kategorial Perempuan (PKP). Adapun anggota PKP adalah setiap perempuan yang sudah menikah atau belum tetapi umur lebih dari 30 tahun. Setiap sekpel mempunyai kriteria luas wilayah yang terdapat sekitar 30 - 50 Kepala Keluarga (KK), sehingga jumlah rata-rata KK berkisar 330 - 550 KK. Berdasarkan informasi yang dituliskan dalam lembar Warta Jemaat, bahwa setiap minggu selalu ada perempuan sebagai ibu rumah tangga mengalami berbagai jenis penyakit baik di rawat atau pun tinggal di rumah. Berdasarkan hasil komunikasi singkat setelah ibadah Minggu diketahui ada beberapa ibu rumah tangga mengalami sakit pada daerah sistem reproduksi seperti mioma dan kista yang harus segera dioperasi sehingga mengalami menapouse dini, sehingga mengganggu aktivitas peran sebagai ibu rumah tangga. Mengacu pada permasalahan tersebut, maka ibu rumah tangga dalam PKP perlu mendapatkan screening kesehatan sistem reproduksi.

Mengacu pada fenomena dan permasalah yang ditampilkan pada perempuan menapouse, maka screening kesehatan sistem reproduksi kepada para perempuan menapouse dapat dilakukan. Adapun alat kesehatan yang digunakan adalah Quantum Resonance Magnetic Analyzer (QRMA). QRMA adalah alat kesehatan dengan 'zero sense' karena mempunyai kerja hanya mengumpulkan frekuensi dan energi tubuh manusia dari sensor medan magnetik melalui handgrip sensor. Alat tersebut membandingkan input yang didapat dari hand grip sensor dengan informasi kesehatan yang berada dalam QRMA. Apabila terjadi penyimpangan dalam proses, secara otomatis QRMA akan menganalisis data dengan Fourier Analyzes method. Kemudian dari hasil tesebut, QRMA hanya mengeluarkan output berupa analisa kondisi dan masalah dalam tubuh yang dicek dan beberapa saran umum sebagai tindakan pencegahan.

\section{METODE}

Screening merupakan suatu deteksi dini terhadap suatu penyakit untuk mengidentifikasikan penyakit atau kelainan klinis yang belum jelas dengan menggunakan tes, pemeriksaan, atau prosedur tertentu yang dapat digunakan secara cepat dan tepat. Adapun alat yang digunakan untuk pelaksanaan screening adalah QRMA Generation (versi mini: $20 \mathrm{~cm}$ x $13 \mathrm{~cm}$ x $4.5 \mathrm{~cm}$ ). Cara kerjanya tidak menimbulkan nyeri dan tindakan tidak invasive serta memberikan analisis dengan akurasi yang tinggi 85\% - 95\% (Vasishta, 2008).

Pada pelaksanaan screening kesehatan sistem reproduksi perempuan meliputi lima aspek yaitu 1) peredaran darah di jantung dan otak, 2) index memori - otak, 3) tingkat kepadatan tulang, 4) kadar gula dalam darah, dan 5) organ reproduksi perempuan. Kelima aspek tersebut penting dikaji secara berkala kepada setiap perempuan mulai dari umur 30 tahun sampai masa menopause. Adapun

$$
\text { Screening Kesehatan Menopause }
$$


alasan dikarenakan penurunan hormon estrogen dapat mempengaruhi fungsi tubuh khususnya pada fungsi kognitif, kepadatan tulang, dan kadar hormon dalam tubuh. Analisa screening dituangkan kedalam tiga kategori normal, berhati-hati, dan berisiko untuk setiap aspek pemeriksaan kesehatan.

Pelaksanaan screening dilakukan kepada peserta $(n=30)$ setelah mendapatkan edukasi tentang perubahan dan dampak menopause pada perempuan di Tangerang. Peserta adalah perempuan umur $35-$ 73 tahun dan tidak ada riwayat dilakukan operasi pada sistem reproduksi. Pelaksanaan screening dilakukan satu hari tanpa diawali oleh puasa makanan dan minuman, serta tidak menimbulkan nyeri karena bukan tindakan invasive atau merusak jaringan. Pelaksanaan screening dilakukan oleh dosen keperawatan yang sudah mendapatkan pelatihan dan pernah melakukan tindakan tersebut.

\section{HASIL DAN PEMBAHASAN \\ Karateristik Peserta Screening}

Umur rata - rata peserta yang mengikuti screening adalah 58.69 tahun, artinya perempuan tersebut adalah kelompok perempuan menopause alamiah. Kejadian menopause alamiah dimulai umur 45 tahun (Singh et al, 2018) dan merupakan masa awal penurunan fungsi verbal memory (Kuh et al, 2018). Oleh karena itu, perempuan menopause harus dilakukan screening kesehatan sistem reproduksi secara teratur untuk mencegah ggangguan kognisi atau dementia.

Pada pelaksanaan screening tersebut, para perempuan juga dikaji berat badan, tinggi badan, dan indeks masa tubuh. $\mathrm{Al}$ ini penting untuk mengetahui derajat kesehatan para perempuan rentang umur 35 75 tahun. Pada hasil diketahui data karateristik berat badan, tinggi badan, dan indeks masa tubuh yang bervariasi (Tabel 1).

Tabel 1. Karateristik peserta berdasarkan berat badan, tinggi badan, indeks massa tubuh $(n=30)$

\begin{tabular}{lcccccc}
\hline Data & Min & Max & Mean & Median & Mode & SD \\
\hline BB & 37 & 89 & 59.41 & 57 & 60 & 12.81 \\
TB & 140 & 168 & 153.34 & 150 & 153 & 5.67 \\
IMT & 16 & 37.5 & 25.24 & 25.3 & 24 & 4.83
\end{tabular}

Pada tabel 1 diketahui berat badan dapat dilihat bahwa peserta yang mengikuti pemeriksaan screening kesehatan tentang sistem reproduksi pada perempuan menopause paling banyak adalah pada kategori berat badan $60 \mathrm{~kg}$, tinggi badan $153 \mathrm{~cm}$, dan indeks massa tubuh $24 \mathrm{~kg} / \mathrm{m}^{2}$. Indeks massa tubuh merupakan faktor resiko yang dapat berpengaruh pada sirkulasi darah dan jantung, kadar kolesterol total, LDL dan trigliserida (Pratama et al, 2015).

Pemeriksaan screening kesehatan yang dilakukan pada peserta diperoleh lima aspek kesehatan yang paling dominan pada perempuan masa menopause yaitu aspek peredaran darah di jantung dan otak, aspek indeks memori, aspek tingkat kepadatan tulang, aspek kadar gula dalam darah, dan aspek organ reproduksi perempuan.

Namun pada pelaksanaan screening kesehatan sistem reproduksi perempuan di Tangerang dijumpai kelemahan yaitu peserta screening tidak dilakukan kaji awal tentang riwayat amenorrhea selama tiga bulan berturut-turut dari masa dilakukan screening. Hal ini dikarenakan kejadian menopause diawali oleh riwayat amenorhoe, sehingga setiap peserta screening umur 42 - 52 tahun harus diawali oleh screening amenorhoe siklus menstruasi selama tiga bulan berturut-turut (Gold et al, 2012).

\section{Screening kesehatan Sistem Reproduksi Perempuan}

Ada tiga kategori untuk hasil screening yaitu normal, berhati-hati, dan berisiko. Pada hasil screening tidak dijumpai kategori normal untuk setiap aspek, sedangkan kategori berhati-hati dan berisiko lebih banyak, sebagai berikut:

Diagram 1. Hasil Pemeriksaan Screening dengan Kategori "berhati-hati"

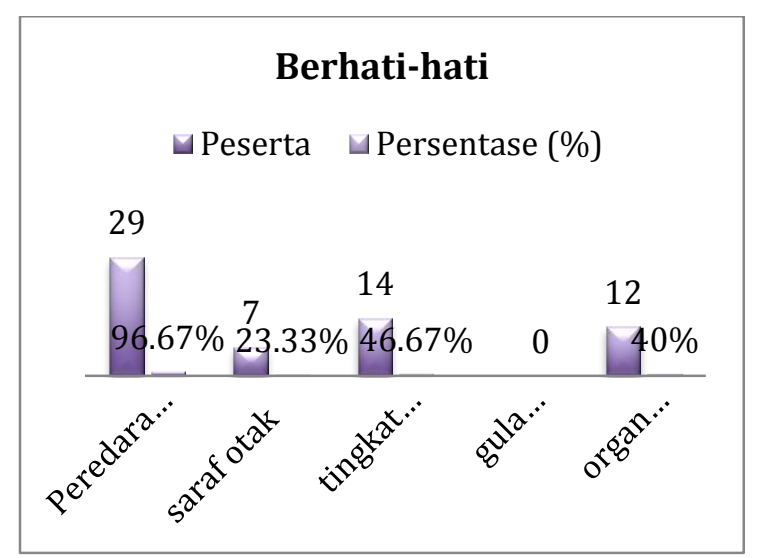

Screening Kesehatan Menopause 
Berdasarkan hasil pemeriksaan yang dilakukan pada 30 responden terdapat 29 peserta (96.67\%) yang paling dominan memiliki masalah di peredaran darah pada jantung dan otak. Kedua organ tersebut akan mengalami adaptasi secara fisiologis melalui reaksi respon tubuh yang dapat diketahui melalui pengukuran tekanan darah dan nadi. Perubahan fisik yang terjadi pada sistem peredaran darah pada jantung dan otak dapat mengakibatkan risiko penyakit degeneratif yang sering terjadi usia lanjut yang mencakup perubahan aorta dan pembuluh darah sistemik sehingga berpengaruh pada tekanan darah, baik tekanan darah sistolik maupun tekanan darah diastolik.

Pada perempuan menopause diketahui terjadi penurunan hormon estrogen dalam darah, dimana hormon tersebut memiliki efek pada sistem kardiovaskular sehingga berpengaruh terhadap peningkatan darah. Terjadinya peningkatan tekanan darah karena reseptor estrogen berpegaruh terhadap pengaturan mekanisme pelebaran pembuluh darah saat otot polos berelaksasi pada dinding pembuluh darah, biovabilias Nitric Oxide meningkat, sel otot polos terhambat pertumbuhannya, poliferasi terpicu akibat adanya kerusakan, sistem renin-angiotensinaldosteron terhambat, dan sistem saraf simpatis terhambat oleh sistem endotelin (Barton dan Meyer, 2009).

Hal ini sejalan juga dengan penelitian yang dilakukan oleh Iriani (2014) menunjukkan bahwa ada hubungan asupan lemak dengan tekanan darah sistolik dan diastolik pada wanita menopause. Selain terjadi peningkatan tekanan darah, penurunan hormone estrogen dapat mengakibatkan gangguan metabolisme lemak yang ditandai dengan kadar kolesterol dalam darah tidak stabil. Hal ini dapat menimbulkan terjadinya peningkatan tekanan darah dan aterosklerosis, khususnya pada perempuan umur diatas 42 tahun atau yang sudah mengalami menopause (Singh et al, 2018).

Mengacu pada pendapat tersebut, maka setiap perempuan menopause harus dilakukan screening kesehatan sistem reproduksi khusunya pada lima aspek yang erat kaitannya dengan penurunan kognitif perempuan menopause. Berdasarkan hasil screening perempuan di Tangerang, diketahui data kategori "berhati-hati" yang paling dominan adalah masalah peredaran darah pada jantung dan otak. Padahal aspek jantung dan otak merupakan elemen penting pada fungsi kognitif atau organ otak.

Selain permasalahan peredaran darah dan jantung, para perempuan menopause yang dilakukan screening mempunyai risiko terhadap masalah syaraf otak dan tingginya gula dalam darah. Hal ini dikarenakan perempuan menopause umur $40-45$ tahun mempunyai kecenderungan mengalami perubahan yang bervariasi tetntang syaraf sympathic seiring bertambahnya umur (Dureja et al, 2017), Keadaan tersebut dijumpai pada hasil screening perempuan di Tangerang yaitu aspek syaraf otak dan gula dalam darah menujukkan angka yang paling banyak dijumpai (diagram 2).

Diagram2. Hasil Pemeriksaan Screening dengan Kategori "Resiko"

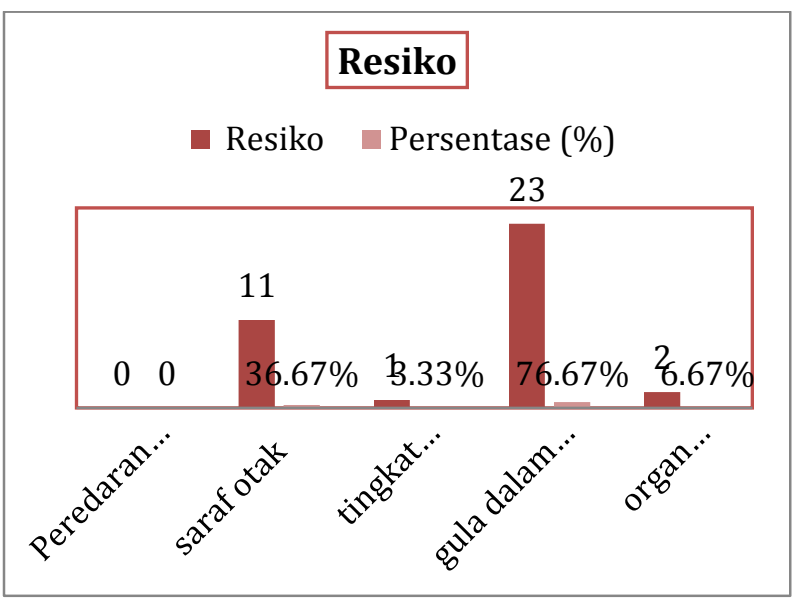

Berdasarkan hasil pemeriksaan screening kesehatan $(\mathrm{n}=30)$ dengan kategori "resiko" yang paling dominan adalah masalah pada gula dalam darah $(76.67 \%)$.

Penurunan hormon estrogen juga mempengaruhi sel - sel tubuh terhadap insulin, sehingga mengakibatkan perubahan gula dalam darah. Adanya perubahan gula dalam darah menyebabkan tidak terkontrolnya kadar gula dalam darah, sehingga memiliki resiko komplikasi diabetes yang lebih tinggi.

Saat ovarium berhenti memproduksi hormon estrogen, maka hormon estrogen akan diproduksi dari androstenedion yang dihasilkan glandula adrenal. Proses tersebut terjadi di dalam jaringan lemak sehingga mengakibatkan banyak perubahan pada wanita menopause. Berkurangnya produksi protein adiponektin yang diakumulasi pada lemak Screening Kesehatan Menopause 
abdomen sentral pada perempuan menopause membuat sel - sel tubuh lebih sensitif terhadap insulin. Rendahnya kadar adiponektin dalam serum berhubungan dengan kondisi resistensi insulin yang dapat membuat kadar gula dalam darah tidak stabil.

Penelitian yang dilakukan Jarret (1968) menunjukkan bahwa siklus menstruasi lebih singkat atau pendek dipengaruhi oleh seksresi hormon estrogen. Penelitian oleh Walsh (1978) menguatkan bahwa menstruasi merupakan faktor dari pengontrol diabetes. Kedua penelitian ini berkaitan bahwa gangguan siklus menstruasi disebabkan oleh karena adanya persamaan hormon yang ikut mengatur mekanisme antara diabetes mellitus dengan gangguan siklus menstruasi. Dua hormon yang ikut mengatur dalam pengontrolan gula dalam darah salah satunya yaitu hormon estrogen, dimana resptor hormon tersebut mengakibatkan pelepasan insulin untuk proses homeostasis glukosa.

Hal ini sejalan dengan hasil screening menunjukkan pada kategori "resiko" yang paling dominan adalah masalah pada gula dalam darah.

Pelaksanaan screening kepada perempuan umur 35 - 75 tahun $(n=30)$ merupakan tindakan lanjutan setelah pemberian edukasi di satu gereja di Tangerang. Adapun alasan pelaksanaan screening setelah diberikan edukasi untuk memaparkan informasi, sehingga perempuan menjadi paham dan punya persepsi yang benar. Diyakini bahwa informasi yang diterima sudah dapat dipahami, sehingga keingintahuan akan informasi terkait dengan menopause menjadi bagian dari perempuan (Trudeau, et al 2011). Bahkan diketahui pada hasil penelitian lain yang sejenis yaitu karateristik umur, pekerjaan, paritas, dan pekerjaan tidak menjadi pembeda pada hasil proses pembelajaran pada perempuan menopause (Shafaie et al, 2014).

Oleh karena itu, tim PkM memberikan edukasi terkait menopause yang bertujuan agar setiap peserta setelah mengetahui dan memahami dampak menopause pada tubuh, maka setiap peserta mau melakukan screening kesehatan. Berdasarkan hasil kajian diketahui bahwa hampir $70 \%$ peserta yang mengikuti edukasi sudah memahami konsep menopause, sehingga peserta diharapkan mau menerapkan hasil edukasi yang didapatkan seperti melakukan olahraga setiap hari dan mengomsumsi makanan tinggi serat, protein, serta rendah lemak. Sesuai dengan fungsi olahraga pada perempuan masa menopause sebagai pilihan pengobatan alternatif untuk dapat beradaptasi dengan gejala psikologis, vasomotor, somatik dan seksual (Stojanovska, 2014).

Pada akhirnya perempuan tersebut mau dilakukan screening secara sukarela dan berkala untuk deteksi awal kesehatan sistem reproduksi. Pernyataan tersebut pun didukung oleh hasil penelitian kepada perempuan di Turki yaitu tingkat pengetahuan mempunyai hubungan yang signifikan terhadap sikap seseorang melalui koping dan sikap kritis yang ditampilkan (Koyuncu., Unsal., Arslantas, 2018)

Adapun alasan yang dijumpai pada peserta (33.33\%) yang tidak mengikuti screening yaitu: "takut mendengar hasil diagnostik" dan "tidak berani mendengar hasil". Peserta yang paling banyak mengikuti kegiatan screening adalah usia $\geq 60$ tahun (50\%). Hal tersebut sejalan dengan target usia peserta yang diharapkan pada pelaksanaan PkM karena usia merupakan salah satu faktor yang dapat memengaruhi respon tubuh selama masa menopause.

Pada pelaksanaan kegiatan screening kesehatan, faktor yang paling dominan dialami adalah penurunan pada peredaran darah di jantung, otak dan metabolisme gula dalam darah. Hal tersebut sejalan dengan Suparni dan Astutik (2016) bahwa masa menopause menyebabkan penurunan kadar estrogen, penyimpangan pada metabolisme lemak, glukosa dan insulin, kadar kolesterol dalam darah yang berpengaruh pada kehidupan seorang perempuan. Pelaksanaan screening kesehatan pada 368 perempuan yang mengalami berbagai tanda dan gejala menopause diketahui adanya hubungan antara menopause dengan perkembangan gejala depresi dan kesulitan untuk berpikir dan mengalami beberapa penyakit medis sejalan dengan bertambahnya umur (Santoro et al, 2015). Oleh karena itu, maka setiap peserta yang sudah mengikuti Pendidikan kesehatan di gereja dilanjutkan dengan pelaksanaan pemeriksaan kesehatan terkait dengan masa menopause. Hasil pemeriksaan yang diperoleh diharapkan peserta dapat berupaya menjaga dan meningkatkan derajat kesehatan pada masa menopause yang dialami. 


\section{KESIMPULAN}

Kegiatan Pengabdian kepada Masyarakat berjudul Screening Sistem Reproduksi Perempuan Menapouse di satu gereja di Tangerang berjalan dengan lancar. Kerjasama antara tim PkM Fakultas Ilmu Keperawatan dan Kesehatan dengan pihak gereja juga terlaksana dengan baik. Setiap peserta yang hadir pada kegiatan Penkes dan screening juga merasa senang dan semakin memahami informasi tentang kesehatan reproduksi pada masa menopause. Pada akhir acara, para peserta dan juga ketua tim gereja mengatakan bahwa kegiatan yang telah dilakukan sangat bermanfaat dan dapat menjadi acuan bagi mereka untuk membantu meningkatkan derajat kesehatannya. Para peserta dan komponen pelayan dari Gereja juga menyarankan agar kegiatan dapat dilakukan dengan rutin sehingga mereka dapat memonitor kesehatan jemaatnya. Rekomendasi dari tim PkM yaitu melakukan komunikasi untuk menindaklanjuti hasil screening melalui pemeriksaan rutin di klinik gereja setiap hari Minggu setelah ibadah Minggu pagi kepada dokter klinik gereja.

\section{UCAPAN TERIMAKASIH}

Kegiatan Pengabdian kepada Masyarakat ini dapat terlaksana dengan baik dengan dukungan oleh Lembaga Penelitian dan Pengabdian kepada Masyarakat serta Fakultas Keperawatan Universitas Pelita Harapan dengan nomor PkM021/FoN/VI/2018. Tim PkM berterima kasih atas kontribusi yang telah diberikan untuk pelaksanaan kegiatan ini.

\section{REFERENSI}

Badan Pusat Statistik. (2015). Proyeksi Penduduk Indonesia 2005 - 2025. Diakses 31 September 2016; http://www.google.co.id

Barton, Mathias dan Meyer, Matthias R. (2009). Postmenopausal Hypertension Mechanism And Therapy. Jurnal American Heart Assosiation. 2009; Diakses tanggal 21 April 2016. http://hyper.ahajournals.org/content/54/1/11 .full.pdf
Dureja, S., Bhandari, V., Manchandra, KC., Sharma RS., Gupta, M., Bachhel, R. 2017. Comparative ana;ysis of sympathic nervous system activity in pre-menopausal and postmenopauseasl women. National Journal of Physchology, Pharmacy, and Pharmacology.

Kim, S.A, Jung, H. (2015). Prevention of cognitive impairment in the midlelife women. pISSN: 228 pISSN: 2288-6478, eISSN: 2288-6761 http://dx.doi.org/10.6118/jmm.2015.21.1.19 Journal of Menopausal Medicine 2015;21:19-238-6478, eISSN: 2288-6761

North American Menopausal Sosiety. (2016). Symptoms of menopause. IOSR journal of Nursing and Health Science (IOSR-JNHS)

Santoro, N,. Epperson, CN., Mathews, S. (2015). Menopausal Sympthom and their management. Endocrinol Metab Clin North Am. 2015 September ; 44(3):497-515. Doi:10.1016/j.ecl.2015.05.001. Endocrinol Metab Clin North Am. Author manuscript; available in PMC 2016 June 02.

Shafaie, FS., Mirghafourvand, M., Jafari, M. (2014). Effect of education through support group on early sympthom menopause: a randomized controlled trial. Journal of Caring Sciences, 2014, 3(4), 247-256 doi:10.5681/jcs.2014.027 http:// journals.tbzmed.ac.ir/ JCS

Stojanovska, L., Apostolopoulos, V., Polman, R., Borkoles, E. (2014). To exercise or not to exercise, during menopause and beyond. Diakses pada https://www.sciencedirect.com/science/artic le/pii/S0378512214000255 
Suparni, I., Astutik, R. ( 2016). Menopause Masalah dan Penanganannya. Diakses pada https://books.google.co.id/books?id= $\quad \mathrm{I} 9$ kwDwAAQBAJ\& pg=PA32 $\& d q=u s i a+m e n o p a u s e+p a d a+$ penurunan+ fungsi+sirkulasi+jan tung\&hl=id\&sa=X\&ved=0ahUKEwjCi4_m 6eLfAhUIEnIKHdNoCj8Q6AEIKTAA\#v= onepage $\& \mathrm{q}=$ usia $\% 20$ menopause $\% 20$ pada $\%$ 20penurunan $\% 20$ fungsi $\% 20$ sirkulasi $\% 20 \mathrm{ja}$ ntung $\& \mathrm{f}=$ false

Trudeau, KJ., Ainscough, JL., Trant, M., Starker, J., Cosineau, T. (2011). Identifying the educational needs of menopausal women: a fesibility study. Womens Health Issues. 2011 ; 21(2): doi:10.1016/j.whi.2010.10.001.

Vasishta, V.G. (2008). Quantum Magnetic Resonance Therapy (QMR): A novel palliative treatment for terminally ill cancer patients. diakses pada http://www.thejsho.com/pdf/quantum.pdf

Koyuncu, T., Unsal, A., Arslantas, D. 2018. Evaluation of the Effectiveness of Health Education on Menopause Symptoms and Knowledge and Attitude in Terms of Menopause. Journal of Epidemiology and Global Health. 8(1-2), pp. 8-12. DOI: 10.2991/j.jegh.2018.08.103. ISSN 22106006.
Kuh, D., Cooper, R., Moore, A., Hardy, R. 2018. Age at menopause and lifetime cognition: findings from a British birth cohort study. Neurology. (90)19. 2018;90: e1673-e1681. doi:10.1212/WNL.0000000000005486

Singh, N., Shinde, M., Dafal, H., Trivedi, A., Chouhan, Y. 2018. Age at natural menopause and factors affecting menopausal age: a cross-sectional study among postmenopausal female attedees of obstetrics and gynecology outpatient department. International Journal of medical Science and Public Health. 7(12),p $994-1000$

Gold, EB., Crawford, SL., Avis, NE., Crandall, CJ., Matthews, KA., Waetjen, LE., Lee, JS., Thuston, R., Vuga, M., and Harlow, SD. 2012. Factors related to age at natural menopause: longitudinal analyses from SWAN. American Journal of Epidemiology. 178(1). DOI: 10.1093/aje/kws421. Advance Access publication. 
Prosiding PKM-CSR, Vol. 2 (2019)

e-ISSN : 2655-3570 